\title{
Contract for Work (locatio conductio operis) of Transportation and Rustic Praedial Servitude of Way (servitus viae) as Roman Law Institutions for Needs of Rural Logistics
}

\author{
Dr. iur. Allars Apsittis \\ ORCID: 0000-0002-8363-6981 \\ Rīga Stradiṇš University, Latvia \\ jf@rsu.lv \\ Dr. iur. cand. Dace Tarasova \\ ORCID: 0000-0003-0524-4285 \\ Rìga Stradiņš University, Latvia \\ jf@rsu.lv \\ Dr. iur. cand. Jolanta Dinsberga \\ ORCID: 0000-0003-3503-9151 \\ Rīga Stradiņš University, Latvia \\ jf@rsu.lv \\ Dr. iur. cand. Jänis Joksts \\ Rīga Stradiṇš University, Latvia \\ jf@rsu.lv
}

\begin{abstract}
The article deals with the results of the authors' research performed on original sources of Roman Law with reference to legal constructions concerning various types of logistics challenges related to agricultural production and residence in rural areas. Provision of transportation services was regulated by means of a contract for work (locatio conductio operis) - an agreement according to which a contractor / employee as a lessee (conductor, redemptor operis) had obligations to fulfil services or certain work on or from the material supplied by the commissioning party / employer / lessor (locator). An agreement on transportation of goods or passengers was also considered to be a contract for work. A smart answer to infrastructure challenges was the so-called rustic praedial servitudes (servitutes praediorum rusticorum), including a servitude of way / road (via), which granted the owner of a parcel of land non-adjacent to a public road (via publica)
\end{abstract}


Allars Apsītis, Dace Tarasova, Jolanta Dinsberga, Jānis Joksts.

Contract for Work (locatio conductio operis) of Transportation and Rustic Praedial Servitude of Way (servitus viae) as Roman Law Institutions for Needs of Rural Logistics

the right to use the road over a parcel of land belonging to another owner, thus gaining access to the public road. The legal framework of a Roman contract for work of transportation and the rustic praedial servitude of way / road must be recognised as a rather effective solution for challenges of rural logistics at the time.

Keywords: contract for work of transportation, servitude of way, Roman Law, rural logistics.

\section{Introduction}

Both agricultural production and residence itself in rural areas have always been associated with various types of logistics challenges, i.e., the need to supply various production-related cargo, to deliver workforce, to guarantee the acquisition of products and services intended for satisfaction of household needs under the conditions of rural areas, etc. The aforementioned, inter alia, causes demand for the appropriately regulated conditions of usage of transportation services and respective infrastructure.

The highly developed Roman civilisation tried rather successfully to find answers to these challenges; thus, legal solutions included in the institutes of Roman law are undoubtedly worth the attention of modern researchers ${ }^{1}$.

Within the framework of the research, studies and analysis of the primary sources of Roman Law - The Code of Justinian (Codex Iustinianus (C 3.34. tit.; Krueger, 1906), The Digest (Digesta (D 8.1-6. tit., D 19.2. tit.; Krueger \& Mommsen, 1928), The Institutes of Justinian (Iustiniani Institutiones (I 2.3. tit.; Krueger \& Mommsen, 1928) were performed, mostly by applying inductive, deductive and comparative methods.

\section{Results}

Provision of transportation services was regulated by means of a contract for work (locatio conductio operis - Latin). A contract for work (Locatio conductio operis (faciendi)) was an agreement according to which a contractor / employee as a lessee (conductor,

\footnotetext{
${ }^{1}$ As known, within the ancient Roman civilisation, a rather complex and very successful legal basis was set up, so the large and for that time highly developed empire could successfully function. Also, it is necessary to indicate that legal principles created by Romans, in particular in areas of private or civil law, have proven to be so successful that they are still the basis of private law in the West and the entire globalised world (Apsitis, 2015, 91-98; Apsïtis \& Joksts, 2018). Modern-day Latvia belongs to the so-called Continental / Romano-Germanic legal system, and its "Civillikums" (Latvian) - The Civil Law of 1937 demonstrates rather direct influence of Roman private law; it can be stated that someone who does not have awareness and an idea of the fundamental principles of the Roman private law may find The Civil Law of Latvia difficult to understand and complicated to comprehend (Apsitis \& Joksts, 2013). The origin of many modern criminal law institutions is also related to the rather manifested reception or acceptance by the modern law of the legal heritage left by the Romans (see: Apsītis \& Joksts, 2013; Apsītis et.al., 2016).
} 
Allars Apsītis, Dace Tarasova, Jolanta Dinsberga, Jānis Joksts.

Contract for Work (locatio conductio operis) of Transportation and Rustic Praedial Servitude of Way (servitus viae) as Roman Law Institutions for Needs of Rural Logistics

redemptor operis) had obligations to fulfil services or certain work on, or from the material supplied by the commissioning party / employer / lessor (locator). An agreement on the transportation (carriage) of goods or passengers was also considered to be a contract for work (locatio conductio operis) (e.g., see D 19.2.11.3, D 19.2.25.7, D 19.2.60.8; Krueger \& Mommsen, 1928, p. 285, 287, 291).

In accordance with the provisions of Roman law, a contractor / lessee-transporter was liable for any damages caused to the transported cargo regardless whether they were caused by themselves or the involved personnel (D 19.2.25.7; Krueger \& Mommsen, 1928, 28). Simultaneously, if a contractor / lessee was able to prove that they had taken all the necessary precautions as a cautious and attentive man would do, they had to be discharged of liability (D 19.2.25.7; Krueger \& Mommsen, 1928, p. 287).

A contractor / lessee-transporter was liable for preservation of the transported cargo, also regarding protection against any illegal claims of third parties (D 19.2.11.3; Krueger \& Mommsen, 1928, p. 285). They were obliged to pay any possible road taxes / duties (D 19.2.60.8; Krueger \& Mommsen, 1928, p. 291). By exercising the right to demand arising from a hire / lease contract (ex locato actionem), it was possible to require a contractor / lessee-transporter to indemnify for any damages to cargo in the event of a traffic accident (D 19.2.13 pr.; Krueger \& Mommsen, 1928. p. 285; Apsitis \& Tarasova, 2017, p. 100).

An agreement as well as any other contract or pact could be considered invalid if its conditions conflicted with good customs / good morals ${ }^{2}$ (contra bonos mores) (C 8.38.4, C 2.3.6, D 45.1.61, D 50.17.116.pr., etc.; Krueger, 1906, p. 93, 351; Krueger \& Mommsen, 1928, p. 774, 923).

A smart answer to infrastructure challenges was the so-called rustic praedial servitudes (servitutes praediorum rusticorum) (see I 2.3.pr., D 8.1.1, D 8.3.1.pr., etc.; Krueger \& Mommsen, 1928, pp. 13; Krueger \& Mommsen, 1928, p. 143, 146, 147), including a servitude of way / road (via) (Berger, 1953/1991, p. 763), which granted the owner of a parcel of land non-adjacent to a public road (via publica) the right to use the road over a parcel of land belonging to another owner ("rights in a thing of another" - "iuria in re aliena"), thus gaining access to the public road, the right of usage of which could not be denied to anyone ("...uti autem via publica nemo recte prohibetur") (C 3.34.11; Krueger, 1906, p. 142). In other words, the neighbour did not have the right to cross (go or drive along) somebody other's / alien land without establishment of proper servitude (C 3.34.11; Krueger, 1906, p. 142). The servitude of way / road (via) included also the rights

\footnotetext{
2 It should be noted that the Roman concept of "good customs" / "good morals" (boni mores) in conjunction with relevant ideological meanings has been loaned, among others, by modern Latvian legal rules relating to the Labour Law, see, e.g. Labour Law clause 3 part one article 101 (Darba likums, 2001, 101. panta pirmās dal̦as 3. punkts). See also: Tarasova, 2016.
} 
Allars Apsītis, Dace Tarasova, Jolanta Dinsberga, Jānis Joksts.

Contract for Work (locatio conductio operis) of Transportation and Rustic Praedial Servitude of Way (servitus viae) as Roman Law Institutions for Needs of Rural Logistics

granted by two other types of servitudes, i.e., the servitude of path (iter) and the servitude of (cattle) driving (actus).

It should be noted that, for addressing the needs of land-based logistics in case of rural properties (estates) (rusticorum praediorum), a number of real servitudes or rights could be established: servitude of path (iter), servitude of (cattle) driving (actus), servitude of way / road (via) (see I 2.3.pr., D 8.3.1. pr. ${ }^{3}$; Krueger \& Mommsen, 1928, p. 13).

Servitude of path (iter) gave the right to cross (ius eundi) the encumbered property (estate), the right for humans to walk on foot, but did not give the right to propel or drive through (agendi) any yoke animals / cattle (iumentum) or vehicle (vehiculum) ("Iter est ius eundi ambulandi homini, non etiam iumentum agendi.") (D 8.3.1.pr.; Krueger \& Mommsen, 1928, pp. 146, 147) / ("Iter est ius eundi, ambulandi homini, non etiam iumentum agendi vel vehiculum...") (I 2.3.pr.; Krueger \& Mommsen, 1928, pp. 13). However, servitude of path gave the right to move not only on foot but also on horseback (“...qua quis pedes vel eques commeare potest”) (D 8.3.12; Krueger \& Mommsen, 1928, pp. 147). Likewise, the transport of someone in a chair or stretcher carried by others was considered to be walking ("Qui sella aut lectica vehitur, ire...") (D 8.3.7.pr.; Krueger \& Mommsen, 1928, pp. 147).

Servitude of (cattle) driving (actus) meant rights to propel or drive (ius agendi) over encumbered property (estate) the cattle or yoke animals used for transportation (iumentum), or vehicles, trailed implements and equipment (vehiculum) ("Actus est ius agendi vel iumentum vel vehiculum") (D 8.3.1.pr.; Krueger \& Mommsen, 1928, pp. 146-147)) / ("actus est ius agendi vel iumentum vel vehiculum") (I 2.3.pr.; Krueger \& Mommsen, 1928, p. 13)). Hence, those who owned servitude of (cattle) driving were able to drive a wagon as well as to propel yoke animals ("Qui actum habet, et plostrum ducere et iumenta agere potest" (D 8.3.7.pr.)) (Krueger \& Mommsen, 1928, p. 147). Both crossing with herd and vehicle driving was allowed (“...et armenta traicere et vehiculum ducere liceat" (D 8.3.12)) (Krueger \& Mommsen, 1928, p. 147).

Servitude of (cattle) driving (actum) included also the rights granted by servitude of path (iter), which could even be used without the presence of a yoke animal (sine iumento). In turn, servitude of path (iter) did not include the rights granted by servitude of (cattle) driving (actum) (I 2.3.pr.; Krueger \& Mommsen, 1928, p. 13). Thus,

\footnotetext{
${ }^{3}$ In accordance with this Roman legal tradition, the The Civil Law of Latvia speaks about "Cela servitüts" (Latvian) - "Servitude of Right of Way" by means of which rights may be granted: 1) to a footpath; 2) to a livestock path; and 3) to a roadway, see: The Civil Law article 1156 (Civillikums, 1937, 1156. pants). See also: Dinsberga \& Bite, 2018. Many proprietors face challenges in terms of inability to access their immovable properties due to those not being adjacent to public roads. One of the ways how a person can acquire the right to use their property is to request a court to determine servitude of right of way to access that property (Dinsberga \& Savickis, 2019, pp. 1). Studying the law and historical development of Latvia, it must be noted that they developed in complicated circumstances and under different regimes. However, there was constant work performed in Latvia to develop and improve the foundation of Latvian national private law ("civiltiesības" - Latvian) (Dinsberga, 2020, pp. 3).
} 
Allars Apsītis, Dace Tarasova, Jolanta Dinsberga, Jānis Joksts.

Contract for Work (locatio conductio operis) of Transportation and Rustic Praedial Servitude of Way (servitus viae) as Roman Law Institutions for Needs of Rural Logistics

for those who had servitude of path, there was no servitude of (cattle) driving, in turn for those who had servitude of (cattle) driving were granted servitude of path, even without the presence of a yoke animal (D 8.3.1. pr.; Krueger \& Mommsen, 1928, pp. 146-147). Thereby truly yoke animals could not be driven by one who had only servitude of path (D 8.3.7.pr.; Krueger \& Mommsen, 1928, p. 147).

In addition, it was particularly emphasised that in both cases, i.e., servitude of path and servitude of (cattle) driving, the users of the servitudes had no right to drag heavy loads (stones, logs) through the encumbered property (estate) (D 8.3.7.pr.; Krueger \& Mommsen, 1928, p. 147), thus risking serious damage.

Servitude of way / road (via) meant the rights to cross (ius eundi) the encumbered property (estate) by driving vehicles or on horseback, the rights to propel or drive (ius agendi) cattle or yoke animals, the rights to drag (ius trahendi) heavy objects and the rights for humans to walk on foot. Thus, servitude of way / road (via) included also the rights granted by servitude of path (iter) and the rights granted by servitude of (cattle) driving (actus) "Via est ius eundi et agendi et ambulandi: nam et iter et actum in se via continent" (D 8.3.1. pr.; Krueger \& Mommsen, 1928, pp. 146-147) / “...via est ius eundi et agendi et ambulandi: nam et iter et actum in se via continet" (I 2.3.pr.; Krueger \& Mommsen, 1928, p. 13) / "Qui viam habent, eundi agendique ius habent: plerique et trahendi quoque... referendi" (D 8.3.7.pr.; Krueger \& Mommsen, 1928, p. 147).

Once established, a servitude was also binding to future owners, e.g., in the event of alienation of land (D 8.1.19, D 8.1.20; Krueger \& Mommsen, 1928, pp. 143-144; C 3.34.3.; Krueger, 1906, p. 141) it was linked to the relevant property as the right in rem (C3.34.13.; Krueger, 1906, p. 142). Respectively, when property servient to a property was sold, servitudes also followed ("Cum fundus fundo servit, vendito quoque fundo servitutes sequuntur") (D 8.4.12; Krueger \& Mommsen, 1928, p. 150). This is because, by carrying the same burden, the servitude was able to transfer to buyers just like the estate itself (C 3.34.3; Krueger, 1906, p. 141). Upon selling the land, it was automatically alienated together with all the imposed servitudes. For the estate that someone sold, the servitude was binding even if there was no actual need for the servitude (D 8.1.19; Krueger \& Mommsen, 1928, pp. 143-144).

It was also kept in the event the land was pledged (D 8.1.16; Krueger \& Mommsen, 1928, p. 143) or confiscated in favour of the state (D 8.3.23.2; Krueger \& Mommsen, 1928 , p. 148), in the event the landowner died or was enslaved (D 8.6.3; Krueger \& Mommsen, 1928, p. 153), as well as in case of malicious possession of land (D 8.6.24; Krueger \& Mommsen, 1928, p. 155).

If the property (estate) was pledged, the pledgee was entitled to legal protection of the servitude. It was not unfair to grant a lawful petition to protect the rights of the servitude to the person who received the pledge (D 8.1.16; Krueger \& Mommsen, 1928, p. 143). Just as he was entitled to petition for the recovery of property (estate) itself (D 8.1.16; Krueger \& Mommsen, 1928, p. 143). 
Allars Apsītis, Dace Tarasova, Jolanta Dinsberga, Jānis Joksts.

Contract for Work (locatio conductio operis) of Transportation and Rustic Praedial Servitude of Way (servitus viae) as Roman Law Institutions for Needs of Rural Logistics

If the serving (servitude-encumbered) property or the dominant property (the property to which the servitude agreed) was made public - confiscated for the benefit of the state, in both cases the servitude continued, as each property that was made public remained in its previous condition (D 8.3.23.2; Krueger \& Mommsen, 1928, p. 148).

According to traditional general principles of law, rights in respect to rural property did not disappear due to death of the owner and loss of legal capacity (enslavement - loss of personal freedom) (D 8.6.3; Krueger \& Mommsen, 1928, p. 153). In other words, death of the owner or loss of the owner's freedom did not stop the existence of servitudes.

The servitude was preserved even if the possessor of the property (estate) was in bad faith (D 8.6.24; Krueger \& Mommsen, 1928, p. 155).

A servitude could be established based on either an agreement, i.e., a pact / contract (stipulation), or a testament (I 2.3.4; Krueger \& Mommsen, 1928, p. 13, 143; D 8.1.5.pr.; C 3.34.3; Krueger, 1906, p. 141).

If somebody wanted to establish rights in favour of their neighbour, it had to be done by the means of pacts and stipulations. It was also possible for anyone to impose an obligation on their heir in the will to allow crossing of bequeathed land on foot or by driving cattle. (I 2.3.4; Krueger \& Mommsen, 1928, p. 13).

It was highlighted that servitude of way / road, servitude of path and servitude of (cattle) driving could be established with almost the same legal techniques by which servitude of use and fruit harvesting (usufruct) might be established (D 8.1.5 pr.; Krueger \& Mommsen, 1928, p. 143). It was also stressed that if all the necessary formalities had been observed - all the necessary steps were taken to establish a servitude - then it was necessary to preserve and protect what had been agreed between the contractors (C 3.34.3; Krueger, 1906, p. 141). For example, the rights for the servitude of way / road, just like other rights related to real estate, could be bought from the landowner. The procedure for transferring the rights to a servitude purchased was to be carried out in the same way as the transfer of possession (D 8.1.20; Krueger \& Mommsen, 1928, p. 144).

However, as it was considered the right in intangible property, a praedial servitude could not be established on the basis of acquisitive prescription - on the grounds of long-term usage (D 8.1.14.pr.; Krueger \& Mommsen, 1928, p. 143). As an additional argument in this regard, reference was made to the specific nature of the servitudes because servitudes are such that they do not allow for certain continuous possession. No one can really walk so persistently and so constantly that at no time interruption of the possession is visible (D 8.1.14.pr.; Krueger \& Mommsen, 1928, p. 143).

One could not establish a servitude that would interfere with the use of another already existing servitude. For example, there are references to the impossibility of assigning a servitude of water course through the same site where someone has already been given a servitude of way / road (D 8.3.14; Krueger \& Mommsen, 1928, pp. 147-148); likewise, if someone was assigned a servitude of water course, it was not possible to sell 
Allars Apsītis, Dace Tarasova, Jolanta Dinsberga, Jānis Joksts.

Contract for Work (locatio conductio operis) of Transportation and Rustic Praedial Servitude of Way (servitus viae) as Roman Law Institutions for Needs of Rural Logistics

or otherwise assign a servitude of path to another in the same location (D 8.3.14; Krueger \& Mommsen, 1928, pp. 147-148).

Width of a servitude road (D 8.3.8, D 8.3.23.pr., D 8.1.13; Krueger \& Mommsen, 1928, pp. 143, 147-148), possibilities of determining the conditions of usage thereof (D 8.1.4.1, D 8.1.4.2, D 8.1.5.1 etc.; Krueger \& Mommsen, 1928, p. 143), liability for violating the conditions of usage (D 8.6.11 pr.; Krueger \& Mommsen, 1928, p. 154), road maintenance / repair procedures (D 8.5.4.5; Krueger \& Mommsen, 1928, p. 151) etc. were also regulated.

It was pointed out that the width of a servitude road according to the Law of the Twelve Tables in a straight piece is eight feet, in a bend, i.e., where the road is curved sixteen (D 8.3.8; Krueger \& Mommsen, 1928, p. 147). Depending on the actual needs, a servitude road could be set either wider or narrower than eight feet, but its width should still be where a vehicle can go, otherwise it would be a servitude of path, not a servitude of way / road (D 8.3.23 pr.; Krueger \& Mommsen, 1928, p. 148). When upon establishing a servitude of way / road its width was not named, it was regulated by law (D 8.3.13.2; Krueger \& Mommsen, 1928, p. 147). For servitude of (cattle) driving and servitude of path, there was a different principle - their width was as indicated, if there was no indication of width, it was to be determined by the arbitrator's decision (D 8.3.13.2; Krueger \& Mommsen, 1928, p. 147).

If the referred location of the road was so narrow that neither vehicle nor a yoke animal could enter, it was considered that servitude of path was obtained rather than servitude of way / road or servitude of (cattle) driving, but if a yoke animal could pass through, but not a vehicle, it was considered that servitude of (cattle) driving was obtained (D 8.1.13; Krueger \& Mommsen, 1928, p. 143).

If servitude of way / road, servitude of path, servitude of (cattle) driving were granted by legacy (legatum) - simply, without specifying the route, the heir was able to choose which part of the property he would allow to make the servitude be established, provided that there was no harm emerging for the legatee (D 8.3.26; Krueger \& Mommsen, 1928, p. 148).

Restrictions could be added to servitudes, for example, to determine what type of vehicle to drive or not (e.g., use for a horse only) or to foresee weight restrictions - so that only a certain weight of the carriage would be carried, or that some herd would be moved or coal / charcoal would be carried (D 8.1.4.1; Krueger \& Mommsen, 1928, p. 143).

Time restrictions (modum) could be set for servitude use - day and hour intervals ("Intervalla dierum et horarum...") (D 8.1.4.2; Krueger \& Mommsen, 1928, p. 143). Use of servitudes could be divided by clock-times - specified hours or days. For example, for usage from the third to the tenth hour, or every other day (D 8.1.5.1; Krueger \& Mommsen, 1928, p. 143). Similarly, it was indicated that for servitude of path, nothing prevents establishing that someone only at daytime can go because for urban properties it was almost a necessity (D 8.4.14; Krueger \& Mommsen, 1928, p. 150). 
Allars Apsītis, Dace Tarasova, Jolanta Dinsberga, Jānis Joksts.

Contract for Work (locatio conductio operis) of Transportation and Rustic Praedial Servitude of Way (servitus viae) as Roman Law Institutions for Needs of Rural Logistics

In case of violation of servitude rules - for example, if someone who was assigned a servitude of way / road or a servitude of (cattle) driving ("via vel actus") to use a particular type of vehicle ("ut vehiculi certo genere uteretur") had used another type of vehicle ("alio genere fuerat usus"), or more cargo / weight than allowed would have been carried ("amplius oneris quam licuit vexerit"), or a wider piece of servitude of path would have been used ("latiore itinere usus esset") or if more yoke animals were driven than allowed ("aut si plura iumenta egerit quam licuit"), due to such violations servitude was not lost ("servitus quidem non amittitur"); however, parties were not entitled to violate the terms agreed upon while establishing the servitude ("quam pactum est in servitute habere") (D 8.6.11pr.; Krueger \& Mommsen, 1928, p. 154).

Regarding maintenance and repair of a servitude road, a general principle was applied according to which the essence of any servitude is that it may force one to tolerate or not to do something (refrain from action) but it cannot oblige anyone to do something or to make any improvements (D 8.1.15.1; Krueger \& Mommsen, 1928, p. 143). Thus, maintenance costs of the servitude road had to be borne by the user owner of the dominant land for whose benefit the servitude was established - and not by the owner of the servient land who was forced only to tolerate the existence of the servitude.

If the maintenance and use of the servitude road was somehow disturbed - for example, someone did not allow the construction or repair of stone pavement ("...reficere sternere non patiatur"), the user / beneficiary of servitude was entitled to bring an action for the acknowledgement of his rights ("confessoria actione ... utendum") regarding the servitude. In the same manner, it was possible to deal with a tree belonging to a neighbour that had obstructed a servitude road or path, thus made it impassable or unusable. As to repairs needed for a servitude road, an interdict could also be used except situations when someone would like to cover the servitude road with the stone pavement unless it was specifically agreed (D 8.5.4.5; Krueger \& Mommsen, 1928, p. 151).

\section{Conclusions}

Under Roman law, provision of transportation services was regulated by means of a contract for work (locatio conductio operis). A contract for work was an agreement according to which a contractor / employee as a lessee had obligations to fulfil services or certain work on or from the material supplied by the commissioning party / employer / lessor. An agreement on transportation (carriage) of goods or passengers was also considered to be a contract for work.

A smart answer to infrastructure challenges was the so-called rustic praedial servitudes (servitutes praediorum rusticorum), including servitude of way / road (via), which granted the owner of a parcel of land non-adjacent to a public road (via publica) the right to use the road over a parcel of land belonging to another owner, thus gaining 
Allars Apsītis, Dace Tarasova, Jolanta Dinsberga, Jānis Joksts.

Contract for Work (locatio conductio operis) of Transportation and Rustic Praedial Servitude of Way (servitus viae) as Roman Law Institutions for Needs of Rural Logistics

access to the public road. The servitude of way / road included also the rights granted by two other servitudes, i.e., the servitude of path (iter) and the servitude of (cattle) driving (actus).

Once established, a servitude was also binding upon future owners (e.g., in the event of alienation of land) - it was linked to the relevant property as a right in rem. It was also kept in the event the land was pledged or confiscated in favour of the state, in the event the landowner died or was enslaved as well as in case of malicious possession of land. A servitude could be established based on either an agreement, i.e., a pact / contract (stipulation), or a testament. However, as it was considered the right in intangible property, a praedial servitude could not be established on the basis of acquisitive prescription - on the grounds of long-term usage Width of the servitude road, possibilities of determining the conditions of usage thereof, liability for violating the conditions of usage, road maintenance / repair procedures etc. were regulated.

Legal framework of a Roman contract for work of transportation and rustic praedial servitude of way / road must be recognised as a rather effective solution for challenges of rural logistics at the time.

\section{Bibliography}

1. Apsītis, A. (2015). Romiešu sabiedrības (societas) līgums un romiešu tiesiskie principi mūsdienu Latvijas tiesībās [Roman Partnership Agreement (Societas) and Roman Legal Principles in the Law of Modern Latvia]. Electronic Scientific Journal of Law “Socrates”, 3(3), 91-98. https:// doi.org/10.25143/socr.03.2015.3.91-98.

2. Apsītis, A., Joksts, O. (2013). Noziedzīgs nodarījums zādzība (furtum) romiešu tiesību kontekstā [Offence of Theft (furtum) In The Context of Roman Law]. Administratīvā un Kriminālā Justīija. 1 (62), 7-14. ISSN 1407-2971.

3. Apsītis, A., Joksts, J. (2018). State officials and illicit asset-grabbing: The Roman approach. SHS Web Conf., 40, 01012, DOI: https://doi.org/10.1051/shsconf/20184001012.

4. Apsītis, A., Joksts, J., Antanavičienè, J. (2016). Threats to sustainable development: asset grabbing phenomenon and the legal concept of Force and Fear in Roman Law. JSSI, 6(2): 291-297. DOI: http://dx.doi.org/10.9770/jssi.2016.6.2(8), https://journals.lka.lt/journal/jssi/article/1466/info.

5. Apsītis, A., Tarasova, D. (2017). Nomas jeb īres līguma piemērošana darba tiesisko attiecību reglamentēšanai jeb romiešu darbu īres līgums un romiešu darbuzṇēmuma līgums. [Adaptation of Lease / Hire Contract in Regulation of Employment Relationship, or Roman Contract of Employment and Roman Contract for Work.] Electronic Scientific Journal of Law "Socrates", 3(9), 91-106. https://doi.org/10.25143/socr.09.2017.3.91-106.

6. Berger, A. (1953/1991). Encyclopedic Dictionary of Roman Law. Philadelphia: The American Philosophical Society.

7. Dinsberga, J. (2020). Compulsory divided property - problems and solutions within modernisation of Latvian legal system. SHS Web of Conf., 85, 01006. DOI: https://doi.org/10.1051/ shsconf/20208501006. 
Allars Apsìtis, Dace Tarasova, Jolanta Dinsberga, Jānis Joksts.

Contract for Work (locatio conductio operis) of Transportation and Rustic Praedial Servitude of Way (servitus viae) as Roman Law Institutions for Needs of Rural Logistics

8. Dinsberga, J., Bite, K. (2018). Legal consequences and problems of the servitudes of right of way established by administrative acts in Latvia. SHS Web Conf., 40, 01011. DOI: https://doi. org/10.1051/shsconf/20184001011.

9. Dinsberga, J., Savickis, V. (2019). Legal and practical aspects of establishing servitude of right of way by court judgment within the framework of urban and rural development and changing global conditions. SHS Web Conf., 68, 01024. DOI: https://doi.org/10.1051/shsconf/20196801024.

10. Krueger, P., ed., (1906). Corpus Iuris Civilis. Codex Iustinianus. [Body of Civil Law. The Code of Justinian.]. Berlin: Weidmannos.

11. Krueger, P., Mommsen, T., eds. (1928). Corpus Iuris Civilis. Digesta [Body of Civil Law. Digest.]. Berlin: Weidmannos.

12. Krueger, P., Mommsen, T., eds., (1928). Corpus Iuris Civilis. Institutiones [Body of Civil Law. Institutes.]. Berlin: Weidmannos.

13. Latvijas Republikas likums: Civillikums [The Civil Law], Valdības Vēstnesis, Nr. 41, 20.02.1937. Consolidated text with amending laws (in Latvian): https://likumi.lv/doc.php?id=225418.

14. Latvijas Republikas likums: Darba likums [Labour Law], Latvijas Vēstnesis, Nr. 105 (2492), 06.07.2001. Consolidated text with amending laws (in Latvian): https://likumi.lv/ta/id/26019darba-likums.

15. Tarasova, D. (2016). Darba tiesisko attiecību izbeigšanas problemātika Darba likuma 101 panta pirmās dal̦as 3. un 4. punkta gadījumos. [Problems of Termination of Legal Work Relationship on The Basis of Labor Law Section 101, Paragraph 1, Clauses 3, 4.] Electronic Scientific Journal of Law “Socrates", 3(6), 99-107. https://doi.org/10.25143/socr.06.2016.3.99-107. 